\title{
IDENTIFIKASI RISIKO RANTAI PASOK BERBASIS SISTEM TRACEABILITY PADA MINUMAN SARI APEL
}

\author{
Dwi Iryaning Handayani \\ Jurusan Teknik Industri Fakultas Teknik \\ Universitas Panca Marga Probolinggo \\ Jalan Yos Sudarso 107 Pabean Dringu Probolinggo 67271 \\ dwiiryaninghandayani@yahoo.co.id
}

\begin{abstract}
ABSTRAK
Risiko merupakan faktor-faktor yang menghambat operasional pada rantai pasok makanan yang tidak dapat dihindari akan tetapi dapat diminimalisir atau dihilangkan dengan melakukan penanganan risiko yang tepat. Penanganan risiko dalam rantai pasok sangat diperlukan agar dapat meminimalkan biaya, waktu dan kinerja dalam aktifitas rantai pasok. Traceability merupakan suatu sistem yang dapat meningkatkan transparansi dalam rantai supplai dalam mengurangi risiko klaim serta menemukan potensi risiko proses rantai pasok makanan. Oleh karena itu penelitian ini bertujuan untuk mengetahui proses yang terkait dengan traceability dan mengidentifikasi risiko yang terjadi pada rantai pasok makanan berdasarkan informasi sistem traceability. Aktivitas yang terkait dalam membangun sistem traceability antara lain pemeriksaan level stock dan produk minuman sari buah, penerimaan material dari pemasok, pembongkaran inspeksi bahan baku, penyimpanan bahan baku, penyimpanan sari buah di gudang, mengeluarkan sari buah dalam gudang untuk memulai aktivitas proses, inspeksi kualitas produk minuman sari buah, labeling produk jadi, persiapan pengiriman produk jadi, penyimpanan produk minuman sari apel di gudang, pengiriman produk ke distributor. Adapun risiko terjadi yang dapat di tangani dengan traceability yaitu, ketidak sesuaian data dengan produk dan bahan baku di gudang, kekurangan barang dan bahan baku digudang, keterlambatan penerimaan material, ketidak sesuaian barang yang dipesan, material busuk,sari buah rusak di gudang, sari buah tercampur dengan benda lain kesalahan pengangkutan produk, kesalahan dalam pengambilan galon sari buah yang tidak bersifat FIFO, kualitas produk tidak sesuai, kesalahan memberikan identitas, produk rusak digudang, produk cacat dalam perjalanan.
\end{abstract}

Kata Kunci : Risiko, Traceability, Rantai Pasok

\section{PENDAHULUAN}

Setiap aktivitas yang dilakukan oleh perusahaan tidak akan terlepas dari ketidakpastian atau kejadian peristiwa tak terencana yang bisa mempengaruhi aliran bahan dan komponen pada rantai pasok (Svensson, 2000). Ketidak pastian dan dampak dari suatu peristiwa didalam rantai pasok dapat dikatakan dengan risiko (Sinha et al,2004). Risiko ini merupakan faktor-faktor yang menghambat operasional pada rantai pasok makanan, yang mana risiko pada rantai pasok dapat terjadi mulai dari hulu pemasok, pabrik, distribusi, dan sampai hilir distributor, konsumen. Risiko lebih dikaitkan dengan kerugian yang diakibatkan oleh kejadian yang mungkin terjadi dalam waktu tertentu (Jutner et al, 2003). Risiko tidak dapat dihindari akan tetapi dapat diminimalisir atau dihilangkan dengan melakukan penanganan risiko yang tepat. Penanganan risiko dalam rantai pasok sangat diperlukan agar dapat meminimalkan biaya, waktu dan kinerja dalam aktifitas rantai pasok tersebut.

Perusahaan harus waspada dengan risiko yang dapat membahayakan keselamatan jangka pendek jangka panjang rantai pasok mereka dan risiko dapat menggangu dan menunda material, informasi, dan arus kas, yang pada akhirnya dapat merusak penjualan, meningkatkan biaya, atau keduanya (Chopra dan Sodhi, 2004). Biasanya, satu penyebab risiko dapat merangsang lebih dari satu kejadian risiko. Misalnya, masalah dalam suatu sistem produksi pemasok dapat mengakibatkan kekurangan bahan dan menolak peningkatan yang terakhiri karena kurang mampu memasok (Pujawan et al, 2009). Terjadinya risiko dapat mengakibatkan kerugian yaitu sebuah konsekuensi negatif yang tidak diinginkan dan 
ketidak pastian. Salah satu jenis risiko yang terjadi pada produk makanan yaitu keracunan makanan sepanjang tahun 1994/1995 dilaporkan sejumlah 26 kasus yang menyebabkan 1.552 orang menderita dan 25 orang meninggal, sedangkan tahun 1995/1996 dilaporkan sebanyak 30 kasus dengan 92 orang menderita dan 13 orang meninggal, begitu juga dengan produk pangan ditemukan sekitar 9,08\% - 10, 23\% tidak memenuhi persyaratan (Cahyono, 2009). Begitu juga dengan produk Indonesia yang akan diekspor sering ditolak oleh negara pengimpor sebagian besar sekitar 60\% alasan karena produk makanan Indonesia tidak higinis. Pada tahun 2007 terjadi 47 kasus penolakan oleh Jepang dan pada tahun 2008 sebanyak 13 kasus umumnya disebabkan oleh cemaran bakteri. Sedangkan Amerika penolakannya disebabkan oleh adanya kotoran $(66,5 \%)$ dan cemaran $(21,4 \%)$. Oleh karena itu Uni Eropa mewajibkan semua pelaku usaha bidang pangan di setiap negara dan para pengekspor dari negara lain menggunakan sistem traceability untuk mencatat perjalanan pangan mulai dari pemasok sampai konsumen (Food Review Indonesia, 2007). Peran pemerintah dalam menjamin keamanan pangan mengeluarkan kebijakan yang berupa PERMENKP RI Nomor: Per. 01/Men/2007 tentang pengendalian sistem jaminan mutu dan keamanan pangan. Pasal 13 berisi tentang prinsip ketelusuran (traceability) yang menekankan bahwa pelaku usaha pengolahan harus memberikan label atau informasi yang mengidentifikasi ketertelusurannya sesuai dengan persyaratan jenis produk tertentu. Maka dari itu sistem traceability dalam menjamin kemanan pangan penting untuk diperhatikan.

Banyak peneliti meyakini bahwa sistem traceability yang dimiliki perusahaan dapat memberikan manfaat terhadap pengelolaan dan pengurangan risiko, hal ini sesuai dengan beberapa pernyataan peneliti yang berkenaan dengan manfaat traceability. Menurut Kher et al. (2010) traceability bermanfaat dalam menemukan sumber-sumber yang berpotensi menimbulkan risiko. Selain itu, manfaat sistem traceability dapat mengurangi risiko yang berbahaya dalam proses produksi dan dapat dengan cepat meresponnya, mengendalikan potensi yang berisiko tinggi agar dapat mencegah kejadian yang tidak terduga serta memperkuat pengendalian pada potensi yang berisiko (Koreshkov, 2009). Li, (2009) menggunakan sistem traceability untuk memprediksikan risiko pada product recall. Begitu juga dengan Bevilacqua et al. (2009) menyatakan bahwa produsen yang menyimpan bahan baku dan proses produksi memiliki potensi risiko pada pencampuran atau kehilangan identitas rantai produksi yang mungkin terjadi dapat diatasi dengan sistem traceability.

Disamping itu tujuan sistem traceability dapat meningkatkan transparansi dalam rantai supplai, mengurangi risiko klaim, meningkatkan efisiensi (Miranda et al, 2003) dan manajemen risiko (Engelseth, 2009; Vanany, 2012). Dengan demikian diketahui bahwa traceability dapat memberikan informasi yang cepat untuk mencegah, menemukan potensi risiko dan mengurangi risiko pada proses rantai pasok makanan. Oleh karena itu penelitian ini bertujuan untuk mengetahui proses yang terkait dengan traceability di perusahaan dan mengidentifikasi risiko yang terjadi pada rantai pasok makanan berdasarkan informasi sistem traceability.

\section{METODE}

Adapun tahapan yang perlu dilakukan dalam mengetahui risiko yang terjadi pada rantai pasok makanan berdasarkan informasi sistem traceability yaitu: mengidentifikasi entitas/ anggota dari rantai pasok, mengidentifikasi area dari proses bisnisnya, mengidentifikasi aktivitas kerjanya yang terkait dengan traceability, mengidentifikasi risiko yang terjadi berdasarkan informasi sistem traceability.

\section{Mengidentifikasi entitas/anggota dari rantai pasok}

Struktur anggota rantai pasok pada industri apel dibuat untuk mengetahui tahapan yang dilalui mulai dari hulu sampai hilir. Struktur anggota jaringan rantai pasok makanan pada industri sari apel digambarkan pada gambar 1 yang terdiri dari petani, supplier, pabrik, distibutor, retailer, sales, konsumen. Perbedaan industri maka struktur jaringannya juga berbeda, selain itu dalam pemetaan proses terlebih dahulu harus 
mengetahui struktur jaringannya untuk mengatahui aktivitas yang dilakukan dalam tiap rantai.

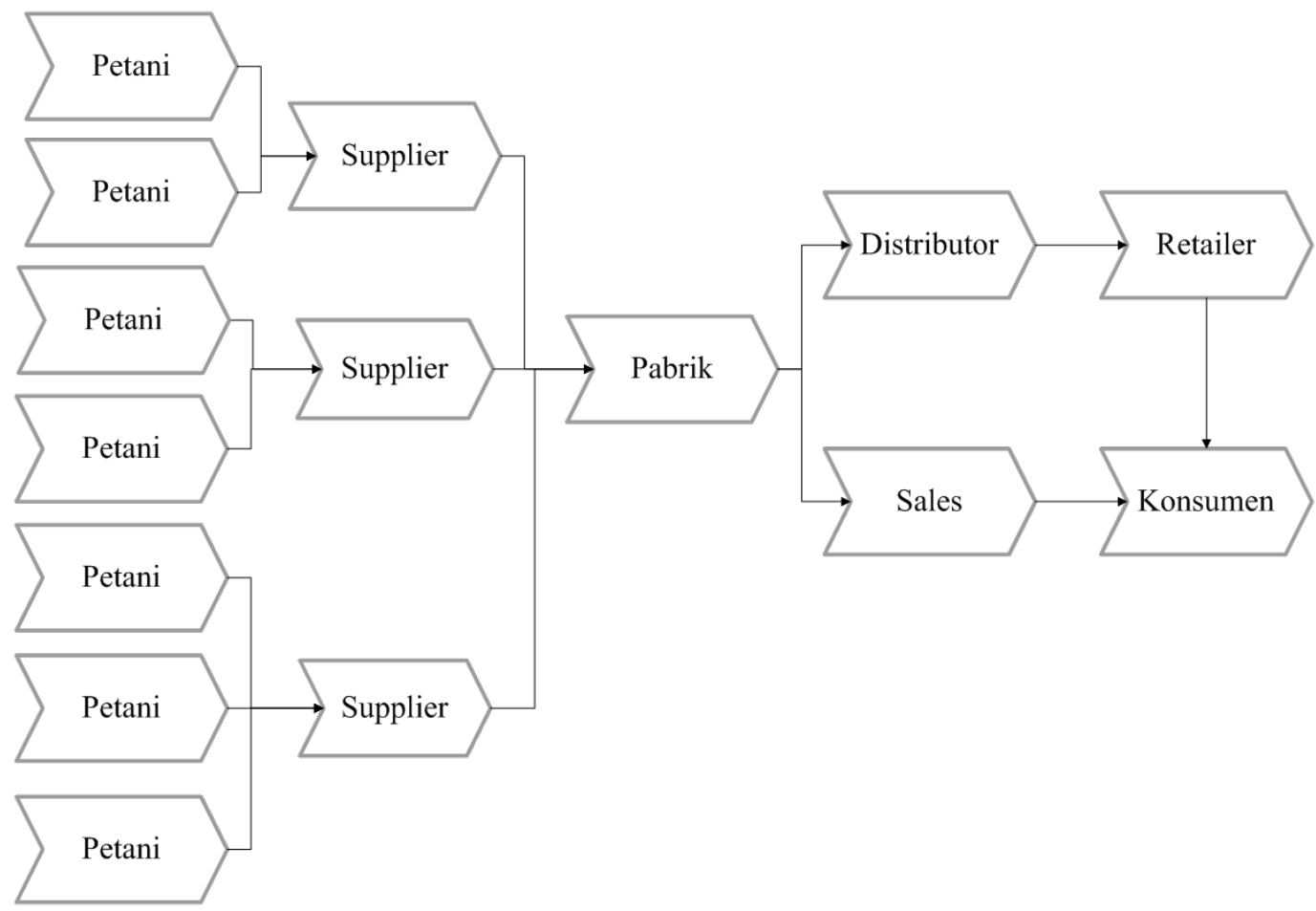

\section{Gambar 1. Struktur Rantai Pasok Industri Sari Apel}

\section{Mengidentifikasi Area Proses Bisnisnya}

Jenis area dari proses bisnis didasarkan pada model SCOR. Model SCOR membagi 5 jenis area yaitu: plan, source, make, delivery, return (suppliers dan customers). Menurut Pujawan (2010), lima proses yang terdapat pada model SCOR berfungsi sebagai berikut : a) Plan adalah proses yang menyeimbangkan permintaan dan persediaan untuk memenuhi kebutuhan pengadaaan. Proses ini mencakup penaksiran kebutuhan distribusi, perencanaan produksi, perencanaan material, perencanaan kapasitas, dan penyesuaian supply chain plan dan financial plan. b) Source adalah proses pengadaan barang atau jasa untuk memenuhi permintaan. Proses ini mencakup penjadwalan pengiriman dari supplier, menerima, mengecek, dan memberikan otorisasi pembayaran untuk barang yang dikirim supplier, memilih supplier, dan mengevaluasi kinerja supplier. c) Make adalah proses transformasi bahan baku menjadi bahan jadi sesuai permintaan konsumen. Kegiatan ini dilakukan berdasarkan ramalan (make to order), pesanan. d) (make to stock), atau engineer to order. Proses ini mencakup penjadwalan produksi, melakukan kegiatan produksi, pengetesan kualitas, mengelola barang setengah jadi, dan memelihara fasilitas produksi. e) Deliver adalah proses pemenuhan permintaan terhadap barang atau jasa. Proses ini meliputi order management, transportasi, dan distribusi. Proses yang terlibat antara lain menangani pesanan dari pelanggan, memilih perusahaan jasa pengiriman, menangani kegiatan pergudangan produk jadi, dan mengirim tagihan ke pelanggan. f) Return adalah proses melakukan atau menerima pengembalian karena berbagai alasan. Kegiatan ini meliputi identifikasi kondisi produk, meminta meminta otorisasi pengembalian cacat, penjadwalan pengembalian, dan melakukan pengembalian. 


\section{Mengidentifikasi aktivitas kerjanya yang terkait dengan traceability}

Penentuan aktivitas yang terkait traceability untuk area proses bisnis disetiap pelaku dari rantai pasok dilakukan setelah mengetahui area proses bisnis untuk setiap pelaku dari rantai pasok. SCOR digunakan untuk menggolongkan aktivitas yang terjadi dari supplier sampai customer sesuai proses yang terdapat pada model SCOR dari tiap aktivitas pada identifikasi untuk membangun sistem traceability.

\section{Identifikasi risiko berdasarkan Proses Bisnis}

Proses identifikasi risiko merupakan tahapan penting untuk mengidentifikasi kejadian risiko (risk event) terhadap proses bisnis yang sudah dibuat. Dengan melakukan pemetaan aktivitas rantai pasok makanan berdasarkan SCOR (plan, source, make, delivery dan return yang disebut bisnis area dalam penelitian ini), selanjutnya pada setiap bisnis area akan dianalisa apa saja yang menjadi risiko, dimanakah risiko tersebut terjadi. Proses identifikasi risiko dan penyebab risiko dilakukan dengan cara literature review, mengetahui kondisi perusahaan, proses bisnis perusahaan, data historis perusahaan, dan stakeholder perusahaan. Mekanisme yang digunakan dalam tahap identifikasi risiko adalah survey, melakukan Focus Group Discussion (FGD) dan wawancara kepada para stakeholder.

III. HASIL DAN PEMBAHASAN

Identifikasi anggota rantai pasok

Identifikasi anggota rantai pasok untuk mengetahui anggota dari rantai pasok yang terlibat pada proses bisnis dalam membangun sistem traceability. Anggota rantai pasok terdiri dari pemasok, pabrik, distributor. Pada tabel 1 menunjukkan anggota rantai pasok dari sistem traceability yang hendak dibangun.

\section{Pelaku Rantai Pasok}

Pelaku rantai pasok merupakan bagian dari anggota rantai pasok yang mana lebih spesifik dalam menjelaskan siapa saja yang akan tererlibat dalam sistem traceability. Adapun rantai pasok yang akan di bangun sistem traceability meliputi: pemasok, pabrik, distributor, sales.

Tabel 1 Anggota rantai pasok pada sistem traceability

\begin{tabular}{|l|c|}
\hline Pelaku rantai pasok & Sistem traceability yang dibangun \\
\hline Pemasok & $\sqrt{ }$ \\
\hline Pabrik & $\sqrt{ }$ \\
\hline Distributor & $\sqrt{ }$ \\
\hline Konsumen & - \\
\hline
\end{tabular}

\section{Identifikasi Area Proses Bisnis}

Jenis area dari proses bisnis mengacu pada model SCOR. Model SCOR membagi 5 jenis area yaitu: plan, source, make, delivery, return (suppliers dan customers). Menurut Pujawan (2010), SCOR berfungsi sbb: 1) Plan adalah proses yang menyeimbangkan permintaan dan persediaan untuk memenuhi kebutuhan pengadaaan. 2) Source adalah proses pengadaan barang atau jasa untuk memenuhi permintaan. 3) Make adalah proses transformasi bahan baku menjadi bahan jadi sesuai permintaan konsumen. 4) Deliver adalah proses pemenuhan permintaan terhadap barang atau jasa. 5) Return adalah proses melakukan atau menerima pengembalian karena berbagai alasan. SCOR digunakan untuk menggolongkan aktivitas yang terjadi petani, pemasok sampai konsumen kemudian mengidentifikasi informasi dari tiap aktivitas tersebut dalam membangun sistem traceability. Adapun area dari proses bisnis untuk sistem traceability terdapat pada tabel 2. 
Tabel 2 Area proses bisnis sistem traceability

\begin{tabular}{|l|l|}
\hline Pelaku rantai pasok & \multicolumn{1}{|c|}{ Area proses bisnis } \\
\hline Petani & Delivery \\
\hline Pemasok & Source \\
\cline { 2 - 2 } & Make \\
\cline { 2 - 2 } & Delivery \\
\cline { 2 - 2 } & Return dari pabrik \\
\hline Pabrik & Plan \\
\cline { 2 - 2 } & Source \\
\cline { 2 - 2 } & Return ke pengepul \\
\cline { 2 - 2 } & Make \\
\cline { 2 - 2 } & Delivery \\
\cline { 2 - 2 } & Return dari distributor \\
\hline \multirow{5}{*}{ Distributor } & Plan \\
\cline { 2 - 2 } & Source \\
\cline { 2 - 2 } & Return dari konsumen \\
\cline { 2 - 2 } & Delivery \\
\hline
\end{tabular}

Tabel 2 menunjukkan bahwa tidak semua yang ada pada struktur rantai pasok menggunakan seluruh komponen yang ada pada model SCOR. Komponen yang digunakan rata-rata empat komponen saja kecuali petani hanya aktivitas delivery yang dilakukan. Komponen make tidak tercantum karena tidak memberikan informasi mengenai proses apa saja yang dilakukan.

\section{Identifikasi aktivitas berdasarkan area proses bisnis}

Penentuan aktivitas yang terkait traceability untuk area proses bisnis disetiap pelaku dari rantai pasok dilakukan setelah mengetahui area proses bisnis untuk setiap pelaku dari rantai pasok. Aktivitas yang dilakukan pada petani terdapat aktivitas delivery yang mengirimkan buah apel ke pemasok. Sedangkan pemasok merupakan perantara antara petani dengan pabrik pengolahan. Para pemasok mengumpulkan buah apel dari beberapa petani dan dilakukan aktivitas make untuk menunjang informasi yang diperlukan dalam sistem traceability yang diberikan saat proses pengiriman. Aktivitas lainnya yang ada di pemasok antara lain source, make, delivery, dan return dari pabrik pengolahan. Aktivitas source yang terdapat pada pemasok adalah penerimaan dan penyortiran sedangkan untuk aktivitas make menggambarkan proses produksi yang dilakukan pada pemasok, yaitu mengumpulkan dan mengemas buah apel dan diberikan label asal buah apel dipanen. Delivery adalah aktivitas pengiriman buah apel ke pabrik pengolahan, return dari pabrik pengolahan merupakan aktivitas pengembalian buah apel dari pabrik pengolah ke pihak pemasok yang disebabkan beberapa faktor, antara lain kualitas kurang baik, ukuran produk tidak sesuai permintaan, dsb.

Seluruh aktivitas yang ada pada model SCOR di gunakan pada pabrik pengolahan, kerena pada pabrik pengolahan aktivitas yang dilakukan lebih kompleks. Pada plan terdapat beberapa aktivitas kegiatan diantaranya: pemeriksaan stok level sari buah dan stok level produk minuman sari buah, perencanaan produksi, perencanaan pengadaan material, perencanaan pengiriman produk dan perencanaan return. Pemeriksaan stok level pada sari buah untuk mengetahui ketersediaan bahan baku yang ada digudang begitu juga dengan pemeriksaan produk jadi minuman sari apel bertujuan 
untuk mengetahui persediaan produk minuman sari apel. Hal ini berkaitan dengan perencanaan produksi dalam menentukan jumlah yang akan diproduksi sesuai dengan jumlah permintaan yang ada. Selain itu jumlah produksi berkaitan dengan perencanaan pengadaan material utama dan material penunjang yang berhubungan terhadap aktivitas source. Perencanaan selanjutnya berhubungan dengan aktivitas pengiriman produk jadi ke distributor dan kekonsumen, aktivitas ini dilengkapi dengan informasi siapa yang mengirim dan kapan produk dikirim, bagaimana pengirimannya. Perencanaan terakhir berhubungan dengan perencanaan return yang berkaitan dengan aktivitas return yang ada di pabrik ke didistributor dan konsumen ke pabrik.

Aktivitas ke dua yaitu source yang dimulai dengan negoisasi pemasok, kontrak pemasok hingga pengeluaran purchase order ke pemasok sampai penerimaan material dari pemasok diperusahaan. Aktivitas inspeksi bahan baku dilakukan setelah pembongkaran bahan baku, penyimpanan bahan baku dilakukan pada bahan baku penunjang sedangkan bahan baku utama penyimpananya sari buah. Inspeksi dilakukan tidak hanya pada bahan baku melainkan pada produk minuman sari apel juga. Produk jadi yang selesai diproduksi tidak langsung dikirim ke konsumen melainkan disimpan di gudang terlebih dahulu hal ini termasuk persiapan pengiriman produk jadi.

Aktivitas make merupakan aktivitas yang berkaitan dengan kegiatan produksi, setelah pelaksanaan kegiatan produksi, finish product diinspeksi secara sampling dan jika lolos inspeksi produk akan dikemas. Produk yang telah dikemas tersebut akan disimpan di gudang sebelumnya dilakukan proses labeling yang menandakan waktu pembuatan, life time produk, asal bahan baku, operator yang bertugas.

Aktivitas keempat adalah deliver, dalam aktivitas ini terdapat beberapa kegiatan yaitu pemilihan jasa transportasi pengiriman, pengiriman ke distributor dan konsumen. Dalam pemilihan jasa transportasi disesuaikan dengan harga, kepercayaan, serta kualitas dalam pengiriman produk hingga ke lokasi yang dituju. Aktivitas terakhir yang kelima yaitu aktivitas return, pada aktivitas ini terdapat dua kegiatan yaitu pengembalian material ke pemasok dan pengembalian produk dari customer. Untuk kegiatan pertama yaitu pengembalian material ke pemasok dilakukan oleh perusahaan jika dalam inspection yang dilakukan pada saat penerimaan material terjadi reject. Sedangkan kegiatan kedua yaitu pengembalian produk dari pelanggan. Aktivitas rantai pasok sistem traceability dapat dilihat pada tabel 3.

Tabel.1 Aktivitas rantai pasok berdasarkan proses bisnis

\begin{tabular}{|c|c|c|}
\hline Pelaku & $\begin{array}{c}\text { Area proses } \\
\text { bisnis }\end{array}$ & Aktivitas \\
\hline Petani & Delivery & Mengirimkan buah apel ke pemasok \\
\hline \multirow{5}{*}{ Pemasok } & Source & Penerimaan dan penyortiran buah apel \\
\hline & \multirow{2}{*}{ Make } & Mengumpulkan dan mengepak buah apel \\
\hline & & Memberikan label \\
\hline & Delivery & Pengiriman ke pabrik \\
\hline & $\begin{array}{l}\text { Return dari } \\
\text { pabrik }\end{array}$ & Menerima pengembalian bahan baku dari pabrik ke pemasok \\
\hline \multirow{7}{*}{ Pabrik } & \multirow{4}{*}{ Plan } & Penentuan jumlah permintaan \\
\hline & & $\begin{array}{l}\text { Pemeriksaan level stok sari buah dan level stok produk } \\
\text { minuman sari buah }\end{array}$ \\
\hline & & Perencanaan produksi \\
\hline & & Perencanaan pengadaan material \\
\hline & \multirow{3}{*}{ Source } & Negoisasi dengan pemasok \\
\hline & & Kontrak dengan pemasok \\
\hline & & Pengeluaran purchase order ke pemasok \\
\hline
\end{tabular}




\begin{tabular}{|c|c|c|}
\hline Pelaku & $\begin{array}{l}\text { Area proses } \\
\text { bisnis }\end{array}$ & Aktivitas \\
\hline & & Penerimaan material dari pemasok \\
\hline & & Pembongkaran dan Inspeksi bahan baku \\
\hline & & Penyimpanan buah apel di gudang \\
\hline & \multirow{5}{*}{ Make } & Penyimpanan sari buah di gudang \\
\hline & & Aktivitas proses produksi \\
\hline & & Inspeksi kualitas produk minuman sari apel \\
\hline & & Pengemasan produk jadi \\
\hline & & Labeling produk jadi \\
\hline & \multirow{3}{*}{ Delivery } & Persiapan pengiriman produk jadi \\
\hline & & Penyimpanan produk minuman sari apel di gudang \\
\hline & & Mengirim ke distributor \\
\hline & \multirow{2}{*}{ Return } & Pengembalian material ke pemasok \\
\hline & & Menerima pengembalian dari distributor \\
\hline \multirow{4}{*}{ Distributor } & Plan & Melakukan Forecasting permintaan sari apel \\
\hline & Source & Menerima produk dari pabrik sari apel dan dilakukan inspeksi \\
\hline & \multirow{2}{*}{$\begin{array}{l}\text { Return ke } \\
\text { pabrik }\end{array}$} & Pengembalian produk ke pabrik \\
\hline & & Menerima pengembalian dari konsumen \\
\hline
\end{tabular}

\section{Aktivitas rantai pasok yang terkait dengan traceability}

Total aktivitas yang ada pada rantai pasok sebanyak 29 aktivitas sedangkan aktivitas yang terkait dengan traceability pada pemasok dan pabrik sejumlah 15 atau 51\% dari aktivitas rantai pasok. Aktivitas rantai pasok yang terkait dengan traceability mulai dari penerimaan bahan baku, proses pembuatan produk dan distribusi. Komponen yang terkait di dalam aktivitasnya yaitu bahan baku, mesin pembuat produksi, sumberdaya manusia. Keterkaitan aktivitas traceability di indikasikan dengan adanya identifikasi ID pada setiap komponen bahan baku, mesin proses produksi, sumberdaya manusia. Sehingga yang dimaksud dengan aktivitas rantai pasok yang terkait dengan traceability yaitu suatu aktivitas yang dapat diidentifikasi dalam memberikan informasi dari aktivitas tersebut dan dapat dilakukan pelusuran apabila terdapat suatu kejadian pada rantai pasok makanan dengan melihat informasi yang diberikan pada masingmasing aktivitas baik unit aliran produk maupun bahan baku. Hal ini bertujuan untuk memberikan informasi data produk dan material dari setiap proses apabila terjadi suatu kejadian yang berkaitan dengan produk dan keamanan pangan.

Tabel 2 Aktivitas untuk sistem traceability

\begin{tabular}{|l|l|l|}
\hline Pelaku & Area proses bisnis & Aktivitas \\
\hline \multirow{3}{*}{ Pemasok } & Source & Penerimaan dan penyortiran buah apel \\
\cline { 2 - 3 } & \multirow{2}{*}{ Make } & Mengumpulkan dan mengepak buah apel \\
\cline { 2 - 3 } & Delivery & Pemberikan label \\
\hline \multirow{2}{*}{ Pabrik } & \multirow{2}{*}{ Plan } & $\begin{array}{l}\text { Pemeriksaan level stok sari buah dan level stok produk } \\
\text { minuman sari apel }\end{array}$ \\
\cline { 2 - 3 } & \multirow{2}{*}{ Source } & Penerimaan bahan baku dari pemasok \\
\cline { 3 - 3 } & & Pembongkaran dan Inspeksi bahan baku \\
\hline
\end{tabular}




\begin{tabular}{|c|c|c|}
\hline Pelaku & Area proses bisnis & Aktivitas \\
\hline & & Penyimpanan buah apel di gudang \\
\hline & Make & Penyimpanan sari buah di gudang \\
\hline & & Aktivitas produksi \\
\hline & & Inspeksi kualitas produk minuman sari buah \\
\hline & & Labeling produk jadi \\
\hline & Delivery & Persiapan pengiriman produk jadi \\
\hline & & Penyimpanan produk minuman sari apel di gudang \\
\hline & & Mengirim ke distributor \\
\hline
\end{tabular}

\section{Identifikasi risiko dengan traceability}

Identifikasi ini dilakukan pada masing-masing proses bisnis dimana traceability bisa dilakukan. Dalam mengidentifikasi risiko traceability dilakukan mulai bahan baku datang sampai distribusi produk dengan mengetahui mana saja risiko yang dapat ditangani dengan sistem traceability di masing - masing aktivitas. Jumlah risiko yang bisa ditangani dengan traceability sejumlah tiga belas kejadian risiko. Ketidak sesuaian data produk dan bahan baku di gudang tergolong jenis risiko traceability karena sistem traceability mampu menelusuri terjadinya ketidak sesuain dengan cara mendapatkan informasi rencana produksi, hasil produksi, jumlah barang yang ada digudang, jumlah barang yang akan dikirim.

Tabel 5 Identifikasi Risiko dengan Traceability

\begin{tabular}{|c|c|c|}
\hline $\begin{array}{l}\text { Area proses } \\
\text { bisnis }\end{array}$ & Aktivitas & Risk Event \\
\hline \multirow[t]{2}{*}{ Plan } & \multirow{2}{*}{$\begin{array}{l}\text { Pemeriksaan level stok sari buah } \\
\text { dan level stok produk minuman } \\
\text { sari buah }\end{array}$} & $\begin{array}{l}\text { Jumlah bahan baku dan produk yang ada } \\
\text { digudang tidak sesuai dengan yang ada di } \\
\text { database perusahaan }\end{array}$ \\
\hline & & $\begin{array}{l}\text { Kekurangan barang dan bahan baku } \\
\text { digudang }\end{array}$ \\
\hline \multirow{3}{*}{ Source } & $\begin{array}{l}\text { Penerimaan material dari } \\
\text { pemasok }\end{array}$ & Keterlambatan penerimaan bahan baku \\
\hline & $\begin{array}{l}\text { Pembongkaran dan Inspeksi } \\
\text { bahan baku }\end{array}$ & Ketidak sesuaian barang yang dipesan \\
\hline & Penyimpanan bahan baku & Material busuk \\
\hline \multirow{5}{*}{ Make } & Penyimpanan sari buah di gudang & Sari buah rusak digudang \\
\hline & Aktivitas produksi & Tercampurnya sari apel dengan benda lain \\
\hline & $\begin{array}{l}\text { Mengeluarkan sari buah dalam } \\
\text { gudang untuk memulai aktivitas } \\
\text { proses }\end{array}$ & $\begin{array}{l}\text { Kesalahan dalam pengambilan sari buah } \\
\text { yang tidak bersifat FIFO }\end{array}$ \\
\hline & $\begin{array}{l}\text { Inspeksi kualitas produk minuman } \\
\text { sari buah }\end{array}$ & Kualitas produk tidak sesuai \\
\hline & Labeling produk jadi & Kesalahan memberikan identitas \\
\hline \multirow{3}{*}{ Deliver } & $\begin{array}{l}\text { Penyimpanan produk minuman } \\
\text { sari apel di gudang }\end{array}$ & Produk rusak digudang \\
\hline & Persiapan pengiriman produk jadi & Kesalahan pengangkutan produk \\
\hline & Pengiriman produk ke distributor & Produk cacat dalam perjalanan \\
\hline
\end{tabular}


Risiko yang bisa direduksi dengan traceability sejumlah tiga belas kejadian risiko, berikut ini analisis terhadap kejadian risiko yang bisa direduksi dengan traceability.Ketidak sesuaian data produk dan bahan baku di gudang tergolong jenis risiko traceability karena sistem traceability mampu menelusuri terjadinya ketidak sesuain dengan cara mendapatkan informasi rencana produksi, hasil produksi, jumlah barang yang ada digudang, jumlah barang yang akan dikirim. Kekurangan barang dan bahan baku digudang salah satu risiko traceability karena dengan traceability dapat diketahui letak ketidak sesuainnya antara pemasaran, produksi dan pengadaan barang. Keterlambatan penerimaan material merupakan risiko traceability karena mampu ditelusuri penyebab keterlambatannya. Ketidak sesuaian barang yang dipesan dapat diatasi dengan membuat standar operation procedure pengadaan barang sampai barang ditrima.

Material busuk merupakan risiko yang dapat mengakibatkan penundaan terhadap pemenuhan permintaan konsumen, risiko ini dapat ditelusuri dengan cara siapa tenaga kerja yang melakukan penerimaan ketika barang datang, bagaimana kondisi awal saat penerimaan dan nama supplier, tanggal masuk. Sari buah rusak digudang adalah risiko yang bisa dikendalikan dengan traceability dengan cara melakukan pengkodean area gudang untuk memastikan proses FIFO serta memperhatikan prosedur penyimpanan misalnya suhu ruangan gudang, peletakkan galon sari buah. Tercampurnya sari apel dengan benda lain, dengan traceability dapat dilakukan penelusuran aktivitas produks terhadap bagaimana persiapan proses produksi, siapa operatornya, kebersihan peralatanya. Kesalahan pengangkutan produk dapat ditelusuri dengan penempatan produk. Kesalahan dalam pengambilan galon sari buah yang tidak bersifat FIFO, risiko ini dapat ditelusuri dengan pemberian kode yaitu kapan di buah diperas, penempatannya. Kualitas produk tidak sesuai merupakan risiko traceability karena dapat ditelusuri dengan mengetahui komposisi bahan baku, zat pewarna, dll serta cara memproduksinya.Kesalahan memberikan identitas dengan cara memperjelas pengkodeaannya dan training pengkodeaan Produk rusak digudang dapat ditelusuri dengan kapasitas gudang, barang yang ada digudang, bagaimana proses peletakkannya, proses pengambilannya. Produk cacat dalam perjalanan, hal yang perlu dilakukan dalam risiko ini yaitu mengidentifikasi nama orang yang mendistribusikan, jenis kendaraan, kapasitas kendaraan serta prosedur pengangkutan.

\section{KESIMPULAN}

Proses bisnis utama dengan SCOR (Plan, Source, make, Deliver) dapat digunakan untuk memetakan proses bisnis yang penting dalam membangun traceability. Ditemukan dari hasil studi kasus ada 11 aktivitas yang terkait dalam membangun sistem traceability dimana satu aktivitas pada plan, tiga aktivitas pada source, empat aktivitas pada make dan tiga aktivitas pada deliver. Adapun aktivitasnya yaitu : Pemeriksaan level stock sari buah dan level stock produk minuman sari buah, penerimaan material dari pemasok, pembongkaran isnpeksi bahan baku, penyimpanan bahan baku, penyimpanan sari buah di gudang, mengeluarkan sari buah dalam gudang untuk memulai aktivitas proses, inspeksi kualitas produk minuman sari buah, labeling produk jadi, persiapan pengiriman produk jadi, penyimpanan produk minuman sari apel di gudang, pengiriman produk ke distributor. Adapun risiko terjadi yang dapat di tangani dengan traceability yaitu, ketidak sesuaian data dengan produk dan bahan baku di gudang, kekurangan barang dan bahan baku digudang, keterlambatan penerimaan material, ketidak sesuaian barang yang dipesan, material busuk,sari buah rusak di gudang, sari buah tercampur dengan benda lain kesalahan pengangkutan produk, kesalahan dalam pengambilan galon sari buah yang tidak bersifat FIFO, kualitas produk tidak sesuai, kesalahan memberikan identitas, produk rusak digudang, produk cacat dalam perjalanan. 


\section{DAFTAR PUSTAKA}

[1] Bevilacqua, M, Ciarapica, F,E, dan Giacchetta, G., (2009), Business process reengineering of a supply chain and a traceability system, A case study, Journal of Food Engineering, 93 (1), 13-22.

[2] Cahyono, Budi (2009) Food Safety dan Implemetasi Quality System Industri Pangan di Era Pasar Bebas, avalableat: www.bappenas.go.id (diakses pada $15 \mathrm{Mei}$ 2012)

[3] Chopra, S. and Sodhi, M.S. (2004), Managing risk to avoid supply-chain breakdown, Sloan Management Review,Vol. 46 No. 1, pp. 53-61.

[4] Engelseth, P., (2009), Food product traceability and supply network integration, The Journal of Business and Industrial Marketing, 24 (5-6), 421-430

[5] Juttner, U., Peck, H., \& Christopher, M. (2003). Supply chain risk management: Outlining an Agenda for future research. International Journal of Logistics: Research and Applications, 6(4), 197-210

[6] Kher, S., Frewer, L.J., De Jonge, J. and Wentholt, M.T.A. (2010), Experts'perspectives on the implementation of traceability in Europe, British Food Journal, Vol. 112 No. 3, 2010, pp. 261-274

[7] Liu (2007) Peraturan standar dan sertifikasi ekspor produk pertanian.Embun Pagi Grafika, Jakarta.

[8] Miranda P. M. Meuwissen, Annet G. J. V., Henk Hogeveen., and Ruud B. M., (2003), Traceability and Certification in Meat Supply Chains, Journal of Agribusiness 21,2(Fall 2003):167S181.

[9] [9] Pujawan, I Nyoman, Geraldin (2009), House of Risk: A model for proactive supply chain risk management, Business Process Management Jounal, Vol 15, No 6.

[10] Pujawan, I.N.\& ER,M. 2010 Supply Chain Management, Surabaya, Guna Widya.

[11] Svensson, G. (2000), A conceptual framework for the analysis of vulnerability in supply chains, International Journal of Physical Distribution \& Logistics Management, Vol. 30 No. 9, pp. 731-49.

[12] Sinha, P.R., Whitman, L.E. and Malzahn, D. (2004), Methodology to mitigate supplier risk in an aerospace supply chain, Supply Chain Management: An International Journal, Vol. 9 No. 2, pp. 154-68.

[13] Vanany,I., Pujawan,I.N.,Setyaningrum, P.,Iryaning, H.,(2012), Business Process Approach For Traceability System, International Conference on Intelligent Manufacturing and Logostics Systems. 